
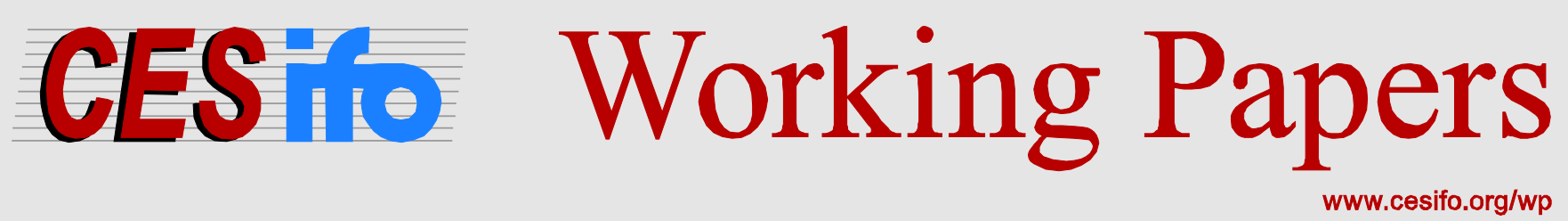

\title{
Tax Competition and Fiscal Equalization under Corporate Income Taxation
}

\author{
Caterina Liesegang \\ Marco Runkel
}

\author{
CESIFO WORKING PAPER NO. 6011 \\ CATEGORY 1: PUBLIC FinANCE \\ JULY 2016
}

An electronic version of the paper may be downloaded

- from the SSRN website:

- from the RePEc website:

- from the CESifo website:

wWw.SSRN.com

Www.RePEc.org

www.CESifo-group.org/wp 


\title{
Tax Competition and Fiscal Equalization under Corporate Income Taxation
}

\begin{abstract}
This paper challenges the view that tax base equalization by the so-called Representative Tax System (RTS) removes inefficient undertaxation in corporate tax competition. The innovation of the paper is that it focuses on a tax on corporate income, instead of the unit tax on capital considered in previous studies. We employ a tax competition model with fiscal equalization and show that the RTS fails to fully internalize pecuniary and fiscal externalities. As consequence, the RTS yields inefficiently low tax rates in the Nash equilibrium of the tax competition game between governments. Tax revenue equalization performs even worse, but combined with equalization of private income it implements the efficient tax rates on corporate income.
\end{abstract}

JEL-Codes: H250, H710, H770.

Keywords: corporate income taxation, tax competition, fiscal equalization.

Caterina Liesegang

University of Technology Berlin

Faculty of Economics and Management

Straße des 17. Juni 135, H51

German- - 10623 Berlin

caterina.liesegang@gmail.com
Marco Runkel

University of Technology Berlin

Faculty of Economics and Management

Straße des 17. Juni 135, H51

German- - 10623 Berlin

marco.runkel@tu-berlin.de

July 16, 2016 


\section{Introduction}

Over the last decades, increased capital mobility has triggered a race to the bottom in corporate taxation. Governments underbid each other in their tax burden levied on firms and thereby engage in detrimental tax competition with inefficiently low tax rates and public funds for providing public goods. The intuition of this argument can be traced back to a fiscal externality: a reduction in the corporate tax rate of one country attracts firms from other countries and so reduce tax revenues of other countries. Since the tax-reducing country does not take into account this effect, corporate tax rates are set inefficiently low. The race to the bottom argument is well-documented both theoretically (e.g. Zodrow and Mieskowski, 1986; Wilson, 1986) and empirically (e.g. Devereux et al., 2008; Hauptmeier et al., 2012; Egger and Raff, 2015). ${ }^{1}$

Interestingly, it has been argued that a fiscal equalization scheme between governments may remove detrimental tax competition. When a government tries to improve its tax revenues by reducing its corporate tax rate, fiscal equalization takes away the additional tax revenues and redistributes it back to the other countries. The net effect of the tax rate reduction on the country's tax revenues is zero and, thus, the country no longer has an incentive to engage in tax competition. Efficiency requires that the marginal equalization transfer just reflects the fiscal externality. The so-called Representative Transfer System (RTS) satisfies this Pigouvian condition under a wide range of assumptions (e.g. Köthenbürger, 2002; Bucovetsky and Smart, 2006; Kotsogiannis, 2010). The RTS aims at equalizing tax bases and is a central element, for instance, in the equalization system of Canadian provinces (Boadway, 2004; Smart, 2007) and German municipalities (Büttner, 2006; Egger et al., 2010).

The present paper challenges the view that the RTS removes inefficient undertaxation in corporate tax competition. The innovation of the paper is that it focuses on an alternative kind of corporate taxation. The previous literature considers unit capital taxation as a short cut of corporate taxation. In contrast, we take into account that in practice corporate taxation is usually represented by a tax on corporate income. More specifically, we employ a multi-country tax competition model with fiscal equalization among countries. Each country is populated by a representative household and a representative firm. Households receive income from owing the firms and supplying (immobile) labor and (mobile) capital. They consume a private good and

\footnotetext{
${ }^{1}$ Surveys of the tax competition literature can be found in Wilson (1999), Wilson and Wildasin (2004) and, more recently, Genschel and Schwarz (2011).
} 
a locally provided public good. Firms demand labor and capital in order to produce the consumption goods. Wage rates and the interest rate are endogenously determined on local labor markets and the world capital market, respectively. The public budget contains public expenditures, on the one side, and an equalization grant as well as the receipts from corporate taxation, on the other side. The equalization grant depends on the tax rates chosen by the governments. The corporate tax is a tax on corporate income with the tax base equal to sales less deductible capital and labor costs.

Within this model, we consider a Nash tax competition game between the governments of the countries. We first characterize the fully symmetric Nash equilibrium of the game and identify pecuniary and fiscal externalities of the corporate tax rates in this equilibrium. The pecuniary externalities reflect the effect of one country's tax rate on capital, wage and profit income of the households in other countries. Even though we focus on the symmetric tax competition equilibrium, the sum of pecuniary externalities is strictly positive in our model. The fiscal externality is the effect of one country's tax rate on tax revenues of the other countries via changes in tax bases. Due to our tax base definition, the sign of this externality is indeterminate. However, we show that the sum of pecuniary and fiscal externalities is positive, implying that in the absence of fiscal equalization the Nash equilibrium of the tax competition game is characterized by inefficiently low corporate tax rates.

We then investigate whether fiscal equalization can correct for this inefficiency. The Pigouvian condition still holds: if the marginal effect of one country's tax rate on this country's equalization transfer reflects all pecuniary and fiscal externalities, then fiscal equalization restores efficiency. In contrast to the previous literature, however, we show that the RTS does not fulfill the Pigouvian condition, but instead leads to inefficiently low tax rates. The intuition goes back to pecuniary and fiscal distortions of the RTS. The pecuniary distortion states that the RTS does not internalize the pecuniary externalities since it aims at equalizing tax bases, not private income. According to the fiscal distortion, the RTS does not even fully internalize the fiscal externality. The reason is that a reduction in one country's tax rate increases the interest rate and thereby tax-deductible capital costs, so the worldwide tax base shrinks. As consequence, the RTS takes away the increase in the tax base of the tax-reducing country, indeed, but this is not enough to compensate the other countries for their reduction in tax bases.

It turns out that the net effect of the pecuniary and fiscal distortions is such that the RTS implies inefficient undertaxation in the tax competition equilibrium. As we will argue in more detail, the net effect can be traced back to the property that under 
corporate income taxation labor costs are tax deductible. We support this intuition by briefly showing that the RTS ensures efficiency in case of unit capital taxes, where the sum of pecuniary externalities is zero (no pecuniary distortion) and where the tax base does not depend on the interest rate (no fiscal distortion), and in case of ad valorem capital taxes, where pecuniary and fiscal distortions of the RTS are both different from zero, but where the net effect of both distortions vanishes since the tax base of the ad valorem capital tax does not depend on the wage rate.

Beside our main result with respect to the RTS, we investigate whether there are alternative equalization schemes that fully correct for the pecuniary and fiscal externalities under corporate income taxation. A partial RTS is not the solution since we have undertaxation already under the full RTS. ${ }^{2}$ A system that equalizes tax revenues instead of tax bases performs even worse, since it also ignores the pecuniary externalities and, thus, causes the same pecuniary distortion as the RTS, and since there is now a further direct effect on tax revenues (for given tax bases) that increases the fiscal distortion, i.e. the part of the fiscal externality that is internalized becomes smaller compared to the RTS. Equalization of private income ignores the fiscal externality and does not fully internalize the pecuniary externalities, again because of the effects of tax rate changes on the world interest rate and the local wage rates. However, when we combine tax revenue and private income equalization, the deficiencies of both systems just compensate each other and we obtain efficient tax rates. Since the RTS causes a smaller fiscal distortion than tax revenue equalization, augmenting the RTS with private income equalization implies inefficiently high corporate income tax rates.

To sum up, our paper shows that, once we model corporate taxation more realistically as corporate income taxation, the RTS is no longer a countermeasure for fighting detrimental tax competition. The usefulness of the widely-used RTS in practice is therefore weakened by our results. The analysis indicates that tax revenue equalization plus private income equalization might theoretically be a good alternative to the RTS. It is an open question, however, whether such a system is realistic. We are not aware of an explicit equalization scheme that tries to equalize both private and public revenues and, of course, the informational requirements for such a system would be even higher than for tax revenue or tax base equalization. On the other hand, it is well known that the EU budget in Europe (e.g. Fenge and Wrede, 2007) and federal taxes and transfers in the US (e.g. Bayoumi and Masson, 1995, Mélitz and Zumer, 2002)

\footnotetext{
${ }^{2}$ Excessive equalization may resolve the problem. But redistributing more than the difference in tax bases seems to be not that realistic from a political point of view.
} 
redistribute national income between member states. Even though this redistribution is not an explicit equalization system as investigated in our paper, it goes a little bit into the direction of the combination of tax revenue and private income equalization.

The internalization of externalities caused by corporate tax competition has already intensively been discussed in the literature. Early contributions investigate how externalities can be internalized by simple matching grants (e.g. Wildasin, 1989; DePater and Myers, 1994). ${ }^{3}$ Smart (1998) was the first who intuitively mentioned that fiscal equalization schemes may correct externalities of tax competition. His argument has been formalized and tested by a number of studies, for example, Janeba and Peters (2000), Dahlby and Warren (2003), Büttner (2006), Smart (2007) and Egger et al. (2010). ${ }^{4}$ Our analysis is closest to Köthenbürger (2002), Bucovetsky and Smart (2006) and Kotsogiannis (2010). These authors use almost the same tax competition framework as we do, but in contrast to our analysis they show that the RTS restores efficiency under a wide range of assumptions. As already mentioned above, the difference to our results is due to the different modeling of corporate taxation. While we consider a tax on corporate income, defined as the difference between sales and deductible factor costs, the above studies assume a unit tax on capital.

Our results are also closely related to two recent articles. Wrede (2014) extends the previous studies by taking into account agglomeration effects. In the version of his model where countries are fully symmetric and tax revenues are used to finance a public good, he comes to the conclusion that a full or partial RTS leads to inefficient undertaxation, similar to our main result. But his result is caused by an agglomeration externality. He sticks to the assumption of unit capital taxes and does not derive corporate income taxation as the reason for the failure of the RTS, in contrast to our analysis. Silva (2016) shows that tax revenue equalization combined with private income redistribution avoids the race to the bottom, similar to our additional result (even though he assumes that private income transfers are paid directly to the households, not to local governments). He derives the result in a model with decentralized leadership of local governments and a unit tax on capital. Hence, his analysis and ours complement

\footnotetext{
${ }^{3}$ DePater and Myers (1994) emphasize the role of pecuniary externalities, which are also key to our analysis. However, the nature of the pecuniary externality in their paper is different from that in our model. While in their paper the pecuniary externality stems from the heterogeneity of countries, in our analysis the pecuniary externalities are non-zero even in the symmetric case.

${ }^{4}$ There is also a literature discussing incentive effects of fiscal equalization in the presence of labor mobility, in contrast to capital mobility considered in our paper. A survey is given in Boadway (2004).
} 
each other since we show the efficiency of tax revenue and private income equalization without decentralized leadership and with a tax on corporate income. Moreover, since Silva (2016) considers a unit capital tax, he does not obtain our main result that the RTS is not efficient under corporate income taxation.

There are further recent studies on fiscal equalization and tax competition. In Gaigné and Riou (2007) trade of the consumption goods is taken into account. Hendriks et al. (2008) investigate the effects of fiscal equalization when countries compete not only in taxes but also in expenditures. Wang et al. (2014) and Ogawa and Wang (2016) investigate whether fiscal equalization has an effect on tax cooperation in a repeated model of tax competition. However, all these studies do not model corporate taxation as a tax on corporate income and therefore cannot derive our results. Lui (2014) takes into account a sales tax which may be interpreted as a special case of a corporate income tax. But his focus is on the effect of equalization on the disciplinary effect of tax competition on public expenditure and, in doing so, he takes tax rates as exogenously given. Therefore, he also does not obtain our results.

The paper is organized as follows. Section 2 describes the basic framework. In Section 3 we characterize the market equilibrium, and in Section 4 the Nash equilibrium of the tax competition game is analyzed. Section 5 contains our results with respect to the effect of fiscal equalization on tax competition. Section 6 briefly discuss other kinds of corporate taxation, and Section 7 concludes.

\section{Basic Framework}

We consider an economy with $n \geq 2$ countries. Throughout it is assumed that all countries are identical. In an analysis of fiscal equalization this assumption seems strange. However, our interest is on the efficiency properties of fiscal equalization, not on equity issues. Focusing on the symmetric case then helps to identify the basic incentives of fiscal equalization for governments. Taking into account country asymmetries would add more complexity without providing further insights beyond those that have already been derived for the asymmetric case in the previous literature.

There is a large number of firms in each country. We suppose all firms are identical and, without loss of generality, focus on the representative firm. In country $i$, the firm produces a (numeraire) good with the help of $k_{i}$ units of the mobile input capital and $\ell_{i}$ units of the immobile input labor. The production function reads $F\left(k_{i}, \ell_{i}\right)$. It exhibits positive and decreasing marginal returns with respect to the two inputs, i.e. $F_{k}>0$, 
$F_{k k}<0, F_{\ell}>0$ and $F_{\ell \ell}<0$. Furthermore, the cross derivative of the production function satisfies $F_{k \ell}=F_{\ell k}>0$, so increasing the quantity of one input raises the marginal return to the other input. The production function is homogeneous of degree $m \in] 0,1\left[\right.$, i.e. $F\left(\lambda k_{i}, \lambda \ell_{i}\right)=\lambda^{m} F\left(k_{i}, \ell_{i}\right)$ for all $\lambda>0$. Assuming $\left.m \in\right] 0,1[$ means that we have decreasing returns to scale. Hence, there is a fixed third production factor like, e.g., land or entrepreneurial services that gives rise to positive economic rents. ${ }^{5}$

Firms are subject to corporate taxation. As emphasized in the Introduction, we deviate from the approach taken in the previous literature and assume a tax on corporate income instead of a unit tax on capital. In most real-world corporate income tax systems, labor costs are fully deductible from the corporate tax base, while capital costs are only partially tax deductible. For example, the costs of debt financing of investment usually reduce the tax base, while the costs of equity financing cannot be deducted. We therefore assume that the firm may deduct the share $\rho \in[0,1$ [ of capital costs from the tax base. Denoting the wage rate in country $i$ by $w_{i}$ and the world interest rate by $r$, the tax base of the firm in country $i$ reads

$$
\phi_{i}=F\left(k_{i}, \ell_{i}\right)-\rho r k_{i}-w_{i} \ell_{i}
$$

It equals revenues less deductible capital and labor costs. With the help of (1), after-tax profits of the firm in country $i$ can be written as

$$
\pi_{i}=\left(1-t_{i}\right) \phi_{i}-(1-\rho) r k_{i}=\left(1-t_{i}\right)\left[F\left(k_{i}, \ell_{i}\right)-\rho r k_{i}-w_{i} \ell_{i}\right]-(1-\rho) r k_{i}
$$

where $t_{i}$ denotes country $i$ 's statutory tax rate.

Each country is populated by a representative household who owns a fixed capital endowment $\bar{k}$ and a fixed labor endowment $\bar{\ell}$. The household earns income $r \bar{k}$ and $w_{i} \bar{\ell}$ from inelastically supplying these factor endowments on the world capital market and the local labor market, respectively. Moreover, the household in country $i$ is the only owner of the firm in country $i$ and, thus, receives the firm's after-tax profits $\pi_{i}$ as profit income. The household uses its total income to buy the numeraire good. Denoting by $c_{i}$ the quantity consumed, the budget constraint of the household in country $i$ reads

$$
c_{i}=r \bar{k}+w_{i} \bar{\ell}+\pi_{i}
$$

\footnotetext{
${ }^{5}$ Put differently, the assumption of decreasing returns to scale generates the corporate income that governments want to tax with the corporate income tax. Note, however, that all our main results also hold for the case of constant returns to scale $(m=1)$. See also footnote 8 .
} 
In addition to the numeraire good, the household consumes the quantity $g_{i}$ of a (local) public good provided by the local government. The utility of the household in country $i$ is represented by the quasi-concave utility function $U\left(c_{i}, g_{i}\right)$.

The equilibrium on the world capital market requires that the firms' aggregate capital demand has to be equal to the households' aggregate capital supply, i.e.

$$
\sum_{j=1}^{n} k_{j}=n \bar{k}
$$

The local labor market in country $i$ is in equilibrium if the firm's labor demand in this country equals the household's labor supply. Formally, we obtain

$$
\ell_{i}=\bar{\ell}
$$

Capital demand $k_{i}$ and labor demand $\ell_{i}$ inter alia depend on the factor prices $r$ and $w_{i}$ according the firm's profit maximization that we consider in detail below. Hence, the factor prices $r$ and $w_{i}$ are endogenously determined by (4) and (5).

\section{$3 \quad$ Market Equilibrium}

The firm in country $i$ maximizes its after-tax profits (2) with respect to capital and labor, taking as given tax rates and factor prices. The first-order conditions read

$$
\begin{gathered}
\left(1-t_{i}\right)\left[F_{k}\left(k_{i}, \ell_{i}\right)-\rho r\right]-(1-\rho) r=0, \\
F_{\ell}\left(k_{i}, \ell_{i}\right)-w_{i}=0,
\end{gathered}
$$

with $i \in\{1, \ldots, n\}$. Due to equation (6), capital is invested in country $i$ up to the point where the after-tax marginal returns equal marginal costs, taking into account deductibility of capital costs. Equation (7) shows that the same is true with respect to labor input, except for replacing the after-tax marginal returns by the before-tax marginal returns since payroll is fully tax deductible. The first-order conditions (6) and (7) together with the market clearing conditions (4) and (5) determine capital input, labor input, wage rates and the world interest rate in the equilibrium of the factor markets as functions of the corporate income tax rates of all countries.

For later purposes, we have to identify the comparative static effects of the tax rates on the market equilibrium. We focus on the symmetric case where countries impose the same tax rate $t_{i}=t$ for all $i \in\{1, \ldots, n\}$. With identical tax rates in all countries 
we obtain $k_{i}=\bar{k}, \ell_{i}=\bar{\ell}, w_{i}=w$ and $\phi_{i}=\phi$ for all $i \in\{1, \ldots, n\}$. Differentiating (4)-(7) and afterwards applying the symmetry assumption, the appendix proves

$$
\begin{gathered}
\frac{\partial r}{\partial t_{i}}=-\frac{F_{k}-\rho r}{n(1-t \rho)}<0, \\
\frac{\partial k_{i}}{\partial t_{i}}=-(n-1) \frac{\partial k_{j}}{\partial t_{i}}=\frac{n-1}{n} \frac{F_{k}-\rho r}{(1-t) F_{k k}}<0, \\
\frac{\partial w_{i}}{\partial t_{i}}=-(n-1) \frac{\partial w_{j}}{\partial t_{i}}=\frac{n-1}{n} \frac{\left(F_{k}-\rho r\right) F_{k \ell}}{(1-t) F_{k k}}<0,
\end{gathered}
$$

with $i, j \in\{1, \ldots, n\}$ and $i \neq j$. Reducing the tax rate in country $i$ lowers capital costs in this country. Hence, capital is reallocated from all other countries to country $i$, as shown in equation (9). According to (8), the reallocation of capital is brought about by an increase in the interest rate. Because of the complementarity of capital and labor $\left(F_{k \ell}>0\right)$, an increase (decline) in capital input increases (lowers) the marginal returns to labor. Thus, the local firm has an incentive to raise labor demand in country $i$, whereas labor demand decreases in all other countries. Since labor input is fixed due to the labor market equilibrium condition (5), these changes in labor demand translate into corresponding changes in the wage rates, as shown in (10).

\section{Tax Competition}

Having investigated the market equilibrium, we can now turn to tax competition among countries. The public budget constraint of country $i$ contains public expenditures $g_{i}$, on the one hand, and corporate tax revenues $t_{i} \phi_{i}$, on the other hand. In addition, we introduce a fiscal equalization scheme that influences the public budget constraint. More specifically, country $i$ 's budget constraint contains the expression $T^{i}(\mathbf{t})$ where $\mathbf{t}:=\left(t_{1}, \ldots, t_{n}\right)$ is the vector of corporate tax rates of all countries. If $T^{i}(\mathbf{t})$ is positive, it represents a transfer that country $i$ receives. For negative values of $T^{i}(\mathbf{t})$ country $i$ makes a contribution to the equalization system. We assume $\sum_{j=1}^{n} T^{j}(\mathbf{t})=0$, so resources collected from one country are fully redistributed to other countries. Taking into account the equalization scheme, country $i$ 's budget constraint reads

$$
g_{i}=t_{i} \phi_{i}+T^{i}(\mathbf{t})
$$

The government of country $i$ sets its tax rate $t_{i}$ in order to maximize utility of its representative household, $U\left(c_{i}, g_{i}\right)$, subject to the private and public budget constraints (3) 
and (11). Moreover, it takes into account the effects of its tax rate on the market equilibrium captured by (8)-(10), but it takes as given the tax policy of all other countries. Hence, we have a non-cooperative tax competition game among the $n$ countries. The Nash equilibrium of this game is determined by $\partial U\left(c_{i}, g_{i}\right) / \partial t_{i}=0$ for all $i \in\{1, \ldots, n\}$.

As all countries are assumed to be identical, we focus on a symmetric equilibrium with $t_{i}=t, k_{i}=\bar{k}, \ell_{i}=\bar{\ell}, w_{i}=w$ and $\phi_{i}=\phi$ for all $i \in\{1, \ldots, n\}$. Using (8)$(10)$, it is straightforward to show that in the symmetric equilibrium the condition $\partial U\left(c_{i}, g_{i}\right) / \partial t_{i}=0$ can be rewritten as

$$
\frac{U_{g}}{U_{c}}=\frac{\phi-n \rho t \bar{k} \frac{\partial r}{\partial t_{i}}+(n-1)(\mathrm{CE}+\mathrm{WE}+\mathrm{PE})}{\phi-n \rho t \bar{k} \frac{\partial r}{\partial t_{i}}-(n-1) \mathrm{FE}+T_{t_{i}}^{i}}
$$

with $^{6}$

$$
\begin{gathered}
\mathrm{CE}=\bar{k} \frac{\partial r}{\partial t_{i}}<0, \mathrm{WE}=\bar{\ell} \frac{\partial w_{j}}{\partial t_{i}}>0, \mathrm{PE}=\frac{\partial \pi_{j}}{\partial t_{i}}=-(1-t) \bar{\ell} \frac{\partial w_{j}}{\partial t_{i}}-(1-\rho t) \bar{k} \frac{\partial r}{\partial t_{i}}>0 \\
\mathrm{FE}=t\left[\left(F_{k}-\rho r\right) \frac{\partial k_{j}}{\partial t_{i}}-\rho \bar{k} \frac{\partial r}{\partial t_{i}}-\bar{\ell} \frac{\partial w_{j}}{\partial t_{i}}\right] \gtreqless 0
\end{gathered}
$$

for $i \neq j$. The expressions in (13) are the pecuniary externalities caused by corporate income taxation. They represent the effect of country $i$ 's tax rate on private income in country $j$. A decrease in country $i$ 's tax rate raises capital income in country $j$ (negative capital income externality $\mathrm{CE}$ ) and lowers wage and profit income in country $j$ (positive wage and profit income externalities WE and PE). Equation (14) contains the fiscal externality, i.e. the effect of country $i$ 's tax rate on country $j$ 's tax revenues via changes in the tax base of country $j$ (positive or negative tax base externality $\mathrm{FE}$ ). In the absence of fiscal equalization, the pecuniary and fiscal externalities determine the deviation of the equilibrium tax rates from their Pareto-efficient (cooperative) level. Formally, this can be seen by setting all externalities and $T_{t_{i}}^{i}$ equal to zero in equation (12). We then obtain the condition $U_{g} / U_{c}=1$ which is the well-known Samuelson rule for the Pareto-efficient supply of the local public good. ${ }^{7}$

For later purposes it is useful to further discuss the signs of the externalities. Let us start with the sign of the sum of pecuniary externalities. Homogeneity of the production

\footnotetext{
${ }^{6}$ The sign of PE follows from using (8)-(10) and the Euler Theorem $m F=\bar{k} F_{k}+\bar{\ell} F_{\ell}$ in the definition of $\mathrm{PE}$ in (13). We obtain $\mathrm{PE}=-(1-m) F_{k}\left(F_{k}-\rho r\right) / n F_{k k}>0$.

${ }^{7}$ The appendix shows that the Samuelson rule really characterizes the Pareto-efficient (cooperative) solution in our model.
} 
function implies $F\left(k_{i}, \ell_{i}\right)=\ell_{i}^{m} H\left(k_{i} / \ell_{i}\right)$ with $H\left(k_{i} / \ell_{i}\right):=F\left(k_{i} / \ell_{i}, 1\right)$ and $H^{\prime}>0>H^{\prime \prime}$. It follows $F_{k}=\ell_{i}^{m-1} H^{\prime}, F_{k k}=\ell_{i}^{m-2} H^{\prime \prime}$ and $F_{k \ell}=(m-1) \ell_{i}^{m-2} H^{\prime}-k_{i} \ell_{i}^{m-3} H^{\prime \prime}$. Using equations (8)-(10) in equation (13) gives

$$
\mathrm{CE}+\mathrm{WE}+\mathrm{PE}=\frac{t\left(F_{k}-\rho r\right) \bar{\ell}^{m-1}}{n(1-\rho t)(1-t) F_{k k}}\left[(1-\rho) \frac{\bar{k}}{\bar{\ell}} H^{\prime \prime}+(1-\rho t)(1-m) H^{\prime}\right] .
$$

Even though we cannot determine the sign of this expression, we can conclude from (15) that, in general, the sum of pecuniary externalities is not equal to zero. For example, if $m$ is close to one, then $\mathrm{CE}+\mathrm{WE}+\mathrm{PE}>0$; if $\rho$ is close to one, then $\mathrm{CE}+\mathrm{WE}+\mathrm{PE}<0 .{ }^{8}$ Only by accident is the sum of pecuniary externalities equal to zero. As we will show in Section 6, this is in contrast to the case of a unit capital tax.

The sign of the fiscal externality FE in (14) is indeterminate because it is not only influenced by the effect of country $i$ 's tax rate on investment in country $j$, as in the case of a unit tax on capital, but due to the tax base definition of a capital income tax also by the effect on the world interest rate and the local wage rate in country $j$. With respect to the sum of all externalities, (8)-(10), (13) and (14) yields

$$
\mathrm{CE}+\mathrm{WE}+\mathrm{PE}+\mathrm{FE}=t\left(F_{k}-\rho r\right) \frac{\partial k_{j}}{\partial t_{i}}>0 .
$$

Hence, the sum of all externalities is positive. This implies that without fiscal equalization tax rates are inefficiently low in the equilibrium of the tax competition game.

\section{Fiscal Equalization}

This inefficiency result holds in the absence of fiscal equalization. However, from (12) it becomes obvious that the equilibrium condition of the tax competition game coincides with the Samuleson rule if and only if

$$
T_{t_{i}}^{i}=(n-1)(\mathrm{CE}+\mathrm{WE}+\mathrm{PE}+\mathrm{FE}) .
$$

Hence, the fiscal equalization system can be used as a Pigouvian instrument to correct for the inefficiency caused by the non-cooperative tax policy. If the marginal transfer

\footnotetext{
${ }^{8}$ In case of $m=\rho=1$ we would have $\mathrm{CE}+\mathrm{WE}+\mathrm{PE}=0$. But note that this is not a meaningful case in our model. With $\rho=1$, the first-order conditions (6) and (7) imply $\phi=F-\bar{k} F_{k}-\bar{\ell} F_{\ell}$. For $m=1$, the Euler Theorem reads $F=\bar{k} F_{k}+\bar{\ell} F_{\ell}$. Hence, for $m=\rho=1$ we have $\phi=0$, i.e. tax bases, tax revenues and public consumption would be zero in all countries, which does not make sense for our purposes. Intuitively, this is plausible since for $m=\rho=1$ we have constant returns to scale and full deductibility of capital costs and, thus, there is no corporate income that governments may tax.
} 
of country $i$ reflects all externalities caused by country $i$ 's tax rate, then country $i$ internalizes the effects of its tax policy on all other countries. As consequence, the tax policy in the tax competition game is identical to the Pareto-efficient (cooperative) tax policy characterized by the Samuelson rule.

This is qualitatively the same insight as the previous literature obtained in the standard tax competition model with a unit tax on capital (e.g. Köthenbürger, 2002; Bucovetsky and Smart, 2006; Kotsogiannis, 2010). An important difference is, however, that the nature of externalities in our framework is different from that in previous studies. This raises the question which type of equalization satisfies the Pigouvian condition (17) and, thus, ensures that the non-cooperative tax policy becomes efficient.

Representative Tax System. The most promising candidate is the so-called Representative Tax System (RTS) that aims at equalizing tax bases of the countries. As mentioned in the Introduction, the previous literature has shown that the RTS corrects for the inefficiency of tax competition under a wide range of circumstances. In our framework, the transfer of country $i$ under the RTS reads

$$
T^{i B}(\mathbf{t})=\bar{t}\left(\bar{\phi}-\phi_{i}\right)
$$

where $\bar{\phi}=\sum_{j=1}^{n} \phi_{j} / n$ is the average tax base and $\bar{t}=\sum_{j=1}^{n} t_{j} \phi_{j} / \sum_{j=1}^{n} \phi_{j}$ is the representative tax rate, i.e. the tax rate that yields the same tax revenues when applied to the world tax base as the sum of regional tax revenues. To illustrate the basic working of the RTS, consider a symmetric situation with identical tax bases. If country $i$ tries to improve its tax base by reducing its tax rate and if this reduction in the tax rate leaves unaltered the average tax base, then the RTS fully redistributes the increase in country $i$ 's tax revenues back to the other countries. Hence, the net effect is zero and country $i$ looses the incentive to lower its tax rate.

Exactly for that reason, the RTS renders the non-cooperative tax policy in the standard tax competition framework with a unit tax on capital efficient (Köthenbürger, 2002; Bucovetsky and Smart, 2006; Kotsogiannis, 2010). In our framework, in contrast, the RTS is not able to restore efficiency. Differentiating (18) with respect to $t_{i}$, taking into account (1), (8)-(10), (13) and (14) and applying symmetry yields

$$
\begin{aligned}
T_{t_{i}}^{i B} & =-\rho t \bar{k} \frac{\partial r}{\partial t_{i}}-t \frac{\partial \phi_{i}}{\partial t_{i}} \\
& =(n-1) \mathrm{FE}+(n-1) \rho t \bar{k} \frac{\partial r}{\partial t_{i}}
\end{aligned}
$$




$$
=(n-1)(\mathrm{CE}+\mathrm{WE}+\mathrm{PE}+\mathrm{FE})-(n-1) t \bar{\ell} \frac{\partial w_{j}}{\partial t_{i}} .
$$

Comparing the last line of equation (19) with equation (17) and taking into account $\partial w_{j} / \partial t_{i}>0$ from equation (10) immediately proves

Proposition 1. Suppose the non-cooperative tax competition game attains a symmetric Nash equilibrium. Then, implementing a fiscal equalization scheme of the RTS type $\left[T^{i}(\mathbf{t})=T^{i B}(\mathbf{t})\right.$ for $\left.i=1, \ldots, n\right]$ leads to inefficiently low non-cooperative tax rates.

The intuition of Proposition 1 can best be explained with the help of (19). Take first a look at the second line of this equation. It shows that the RTS does not internalize the pecuniary externalities CE, WE and PE. This represents the pecuniary distortion of the RTS. The reason is obvious, since the RTS aims at equalizing the countries' tax bases, not their private income. But even if we ignore the pecuniary distortion, the second line of (19) reveals a further reason for the failure of the RTS: tax base equalization does not fully internalize the fiscal externality FE. This is the fiscal distortion of the RTS. To understand the intuition, turn to the first line of (19). If country $i$ tries to improve its tax base by reducing its tax rate, the transfer system redistributes the corresponding increase in country $i$ 's tax revenues back to the other countries, see the expression $-t\left(\partial \phi_{i} / \partial t_{i}\right)$ in the first line of (19). In contrast to the standard tax competition model, however, the worldwide tax base $\sum_{j=1}^{n} \phi_{j}$ does not stay constant but shrinks, since the interest rate and thereby capital costs go up. ${ }^{9}$ As consequence, the average tax base $\bar{\phi}$ falls and, thus, the redistribution system takes away from country $i$ more than the additional tax revenues. This effect is represented by $-\rho t \bar{k}\left(\partial r / \partial t_{i}\right)$ in the first line of (19). But even the increased transfer of country $i$ is not enough to compensate the other countries for their loss in tax revenues, since averaging implies that the fall in the average tax base is smaller than the fall in the worldwide tax base. This is the reason why only a part of the fiscal externality is corrected by the RTS.

As becomes obvious from the third line of (19), the net effect of the pecuniary and fiscal distortions of the RTS is represented by the term $-(n-1) t \bar{\ell}\left(\partial w_{j} / \partial t_{i}\right)$, which is negative due to (10). A closer look at the origin of this expression shows that it comes from the profit income externality PE: a tax rate decrease in country $i$ reduces the wage rate in country $j$ and thereby the deduction of labor costs of the firm in country $j$; as consequence, the firm in country $j$ pays more taxes and realizes lower after-tax profits. Hence, the net distortion of the RTS can be traced back to the property that

\footnotetext{
${ }^{9}$ Formally, using equations (9) and (10) we obtain $\sum_{j=1}^{n}\left(\partial \phi_{j} / \partial t_{i}\right)=-n \rho \bar{k}\left(\partial r / \partial t_{i}\right)>0$.
} 
under corporate income taxation labor costs are tax deductible. Note that this is a realistic property for most corporate tax systems in practice. We will show in the last section that it is a key difference to other kinds of corporate taxation.

At this point a remark on the countries' impact on market prices is in order. The above-mentioned intuition of Proposition 1 heavily relies on the individual country's impact on the world interest rate and the foreign wage rates. One might therefore conjecture that the failure of the RTS vanishes when countries are small and their impact on market prices negligible. But this is not true. Formally, the case of small countries is reflected by our model if the number of countries is large. If we let $n$ converge to infinity, (8) and (10) show that country $i$ 's impact on $r$ and $w_{j}$ really tends to zero. However, the failure of the RTS to fully internalize the externalities still remains as shown by using $n \rightarrow \infty$ in (19). Intuitively, for increasing $n$ the effect of country $i$ on a single (!) other country really vanishes, but the total number of countries increases as well and the effect of country $i$ on the aggregate (!) of the other countries is still strictly positive. ${ }^{10}$ Hence, Proposition 1 and its interpretation also hold for the case of small countries. The same will be true for all results derived below.

Alternative Equalization Schemes. The failure of the RTS stated in Proposition 1 raises the question whether other equalization schemes may restore efficiency. In case that a full RTS does not work, previous studies investigate a partial RTS which equalizes only a part of the difference in tax bases. Formally, such a partial RTS is represented by $T^{i B}(\mathbf{t})=\alpha \bar{t}\left(\bar{\phi}-\phi_{i}\right)$ with $\left.\alpha \in\right] 0,1[$. In our framework, all expressions in the marginal transfer (19) are then multiplied by $\alpha \in] 0,1[$. The degree of internalizing pecuniary and fiscal externalities is therefore reduced and inefficient undertaxation aggravated compared to a full RTS. Hence, a partial RTS is not able to restore efficiency if corporate taxation takes the form of a corporate income tax. ${ }^{11}$

Another alternative discussed in previous studies and employed, for instance, between German states (Baretti et al., 2002) is tax revenue equalization given by

$$
T^{i R}(\mathbf{t})=\overline{t \phi}-t_{i} \phi_{i}
$$

where $\overline{t \phi}=\sum_{j=1}^{n} t_{j} \phi_{j} / n$ equals average tax revenues. Differentiating (20) with respect

\footnotetext{
${ }^{10}$ Formally, the effect on one other country is multiplied by $1 / n$ which tends to 0 for $n \rightarrow \infty$, but the effect on the aggregate of other countries is multiplied by $(n-1) / n$ that converges to 1 if $n \rightarrow \infty$.

${ }^{11}$ Conversely, setting $\alpha>1$ may ensure efficient equilibrium tax rates. But this implies excessive equalization and it is an open question whether such a system is politically feasible.
} 
to $t_{i}$ and taking into account (1), (8)-(10), (13), (14) and (19) yields

$$
T_{t_{i}}^{i R}=T_{t_{i}}^{i B}-\phi \frac{n-1}{n} .
$$

Because $\phi(n-1) / n>0$, we immediately obtain

Proposition 2. Suppose the non-cooperative tax competition game attains a symmetric Nash equilibrium. Then, implementing tax revenue equalization $\left[T^{i}(\mathbf{t})=T^{i R}(\mathbf{t})\right.$ for $i=1, \ldots, n]$ implies non-cooperative tax rates that are even smaller than those under the $\operatorname{RTS}\left[T^{i}(\mathbf{t})=T^{i B}(\mathbf{t})\right.$ for $\left.i=1, \ldots, n\right]$.

The intuition follows from (21). According to this equation, tax revenue equalization triggers the same effects as the RTS and therefore is characterized also by pecuniary and fiscal distortions. But there is now an additional effect reflected by the expression $-\phi(n-1) / n$ in $(21)$. To understand this additional effect note that under tax revenue equalization the reduction in country $i$ 's tax rate has a direct negative impact on country $i$ 's tax revenues and on average tax revenues. Because of averaging, the loss in country $i$ 's tax revenues is larger in absolute terms than the loss in average tax revenues. Hence, the direct effect further reduces the net transfer of country $i$ to the other countries and decreases the part of the fiscal externality that is internalized. In terms of distortions, tax revenue equalization aggravates the fiscal distortion and therefore renders equilibrium tax rates even less efficient.

Since the RTS and tax revenue equalization both fail to internalize the pecuniary externalities, another idea is to consider private income equalization. Formally, private income equalization can be defined by

$$
T^{i P}(\mathbf{t})=\bar{c}-c_{i},
$$

where $\bar{c}=\sum_{j=1}^{n} c_{j} / n$ represents average private income. From (1), (3), (9), (10), (14) and (22) we obtain

$$
\begin{aligned}
T_{t_{i}}^{i P} & =(n-1)(\mathrm{CE}+\mathrm{WE}+\mathrm{PE})-\frac{n-1}{n}\left(-\phi+n \rho t \bar{k} \frac{\partial r}{\partial t_{i}}\right) \\
& =(n-1) t \bar{\ell} \frac{\partial w_{j}}{\partial t_{i}}+\phi \frac{n-1}{n} .
\end{aligned}
$$

The first line in (23) shows that private income equalization does not fully internalize the pecuniary externalities. The reason is that country $i$ 's tax rate again has an effect on the world interest rate (similar to the corresponding effect under both the RTS and 
tax revenue equalization) and a direct effect on the firm's after-tax profits (similar to the effect under tax revenue equalization). Combining (23) with (19) and (21) yields

$$
\begin{aligned}
T_{t_{i}}^{i P}+T_{t_{i}}^{i R} & =(n-1)(\mathrm{CE}+\mathrm{WE}+\mathrm{PE}+\mathrm{TE}), \\
T_{t_{i}}^{i P}+T_{t_{i}}^{i B} & =(n-1)(\mathrm{CE}+\mathrm{WE}+\mathrm{PE}+\mathrm{TE})+\phi \frac{n-1}{n} .
\end{aligned}
$$

Comparing with (17) immediately proves

Proposition 3. Suppose the non-cooperative tax competition game attains a symmetric Nash equilibrium. Then,

(i) implementing private income equalization and tax revenue equalization $\left[T^{i}(\mathbf{t})=\right.$ $T^{i P}(\mathbf{t})+T^{i R}(\mathbf{t})$ for all $\left.i=1, \ldots, n\right]$ renders the non-cooperative tax rates efficient,

(ii) implementing private income equalization and the $R T S\left[T^{i}(\mathbf{t})=T^{i P}(\mathbf{t})+T^{i B}(\mathbf{t})\right.$ for all $i=1, \ldots, n]$ leads to inefficiently high equilibrium tax rates.

Interestingly, the distortions of private income equalization and tax revenue equalization just offset each other and, thus, combining both systems renders the equilibrium corporate tax rates Pareto-efficient, as stated in Proposition 3 (i). Under the RTS, in contrast, the fiscal distortion is not as severe as under tax revenue equalization. Hence, combining RTS with private income equalization redistributes too much resources and thereby gives the countries the incentive to raise the corporate tax rates above their efficient levels, as proven by Proposition 3 (ii).

\section{Comparing with Alternative Tax Systems}

In order to further clarify the intuition of our results, it is useful to consider fiscal equalization under two other kinds of corporate taxation. We will start with briefly repeating the analysis of the unit capital tax already considered in the previous literature and then turn to an ad valorem capital tax as a second, so far unexplored, alternative.

Unit Capital Taxation. Under unit capital taxation, after-tax profits of the firm in country $i$ read $\pi_{i}=F\left(k_{i}, \ell_{i}\right)-\left(r+t_{i}\right) k_{i}-w_{i} \ell_{i}$. The signs of the comparative static effects are the same as in (8)-(10). Analogously to (12), we can show that the Nash equilibrium of tax competition with unit capital taxes is characterized by

$$
\frac{U_{g}}{U_{c}}=\frac{\bar{k}+(n-1)(\mathrm{CE}+\mathrm{WE}+\mathrm{PE})}{\bar{k}-(n-1) \mathrm{FE}+T_{t_{i}}^{i}},
$$


with

$\mathrm{CE}=\bar{k} \frac{\partial r}{\partial t_{i}}<0, \mathrm{WE}=\bar{\ell} \frac{\partial w_{j}}{\partial t_{i}}>0, \mathrm{PE}=\frac{\partial \pi_{j}}{\partial t_{i}}=-\bar{\ell} \frac{\partial w_{j}}{\partial t_{i}}-\bar{k} \frac{\partial r}{\partial t_{i}}>0, \mathrm{FE}=t \frac{\partial k_{j}}{\partial t_{i}}>0$

The transfer under the RTS is now defined as $T^{i B}(\mathbf{t})=\bar{t}\left(\bar{\kappa}-k_{i}\right)$ with $\bar{\kappa}=\sum_{j=1}^{n} k_{j} / n$ and $\bar{t}=\sum_{j=1}^{n} t_{j} k_{j} / \sum_{j=1}^{n} k_{j}$. The marginal effect of country $i$ 's tax rate reads

$$
T_{t_{i}}^{i B}=-t \frac{\partial k_{i}}{\partial t_{i}}=(n-1) \mathrm{FE} .
$$

There are two key differences to the case of corporate income taxation: First, it is straightforward to see from (27) that the sum of pecuniary externalities sum up to zero, i.e. $\mathrm{CE}+\mathrm{WE}+\mathrm{PE}=0$. Second, the tax base under unit taxation does not depend on the world interest rate and, thus, the RTS fully reflects the fiscal externality FE, as shown in (28). These two differences imply that under unit capital taxation the RTS causes neither a pecuniary distortion nor a fiscal distortion. The RTS internalizes all externalities and therefore restores efficiency of equilibrium tax rates. This argument confirms our intuition in the previous section, that under corporate income taxation the RTS fails to restore efficiency, since it causes pecuniary and fiscal distortions.

Ad Valorem Capital Taxation. Under an ad valorem capital tax, after-tax profits of firm $i$ read $\pi_{i}=F\left(k_{i}, \ell_{i}\right)-\left(1+t_{i}\right) r k_{i}-w_{i} \ell_{i}$. Here the interest rate enters the tax base and one might conjecture that the RTS again fails to fully internalize all externalities, as under the corporate income tax. But the contrary will be true. The signs of the comparative static effects are again the same as in (8)-(10). Analogously to (12), the condition for the Nash equilibrium of tax competition can be written as

$$
\frac{U_{g}}{U_{c}}=\frac{r \bar{k}+n t \bar{k} \frac{\partial r}{\partial t_{i}}+(n-1)(\mathrm{CE}+\mathrm{WE}+\mathrm{PE})}{r \bar{k}+n t \bar{k} \frac{\partial r}{\partial t_{i}}-(n-1) \mathrm{FE}+T_{t_{i}}^{i}},
$$

with

$$
\begin{gathered}
\mathrm{CE}=\bar{k} \frac{\partial r}{\partial t_{i}}<0, \mathrm{WE}=\bar{\ell} \frac{\partial w_{j}}{\partial t_{i}}>0, \mathrm{PE}=\frac{\partial \pi_{j}}{\partial t_{i}}=-\bar{\ell} \frac{\partial w_{j}}{\partial t_{i}}-(1+t) \bar{k} \frac{\partial r}{\partial t_{i}}>0, \\
\mathrm{FE}=t\left(r \frac{\partial k_{j}}{\partial t_{i}}+\bar{k} \frac{\partial r}{\partial t_{i}}\right) \gtreqless 0 .
\end{gathered}
$$

The transfer under the RTS is given by $T^{i B}(\mathbf{t})=\bar{t}\left(\overline{r k}-r k_{i}\right)$ with $\overline{r k}=\sum_{j=1}^{n} r k_{j} / n$ and $\bar{t}=\sum_{j=1}^{n} t_{j} r k_{j} / \sum_{j=1}^{n} r k_{j}$. The marginal effect of country $i$ 's tax rate reads

$$
T_{t_{i}}^{i B}=(n-1) \mathrm{FE}-(n-1) t \bar{k} \frac{\partial r}{\partial t_{i}}=(n-1)(\mathrm{CE}+\mathrm{WE}+\mathrm{PE}+\mathrm{FE}),
$$


Similar to the case of corporate income taxation, under ad valorem capital taxation the RTS causes pecuniary and fiscal distortions. The pecuniary distortion can be proven from $(30)$ which implies $(n-1)(\mathrm{CE}+\mathrm{WE}+\mathrm{PE})=-(n-1) t \bar{k}\left(\partial r / \partial t_{i}\right)>0$, i.e. the sum of pecuniary externalities is positive and not internalized by the RTS. The fiscal distortion can be seen from the first part of (32). The key difference to the case of corporate income taxation is that under the ad valorem tax the net effect of the two distortions is zero and equilibrium tax rates are efficient, as formally seen from the second part of (32). The reason for this difference is that the wage rate does not enter the tax base under ad valorem capital taxation. This confirms our intuition for the failure of the RTS under corporate income taxation discussed in the previous section.

\section{Conclusion}

This paper addresses the question whether pecuniary and fiscal externalities arising in tax competition among countries can be internalized by fiscal equalization. The innovation of the analysis is that it explicitly models a corporate income tax, whereas previous studies interpreted corporate taxation as a unit tax on capital. In contrast to the previous literature, we can show that with symmetric countries tax base equalization does not render equilibrium tax rates Pareto-efficient. The reason is that tax base equalization does not internalize pecuniary externalities, which in our framework are usually different from zero, and only partially internalizes the fiscal externality since a tax rate reduction in one country lowers the worldwide tax base. Tax revenue equalization aggravates the latter problem, but combined with private income equalization it just internalizes all externalities and ensures efficient tax rates.

The usefulness of the RTS for removing detrimental tax competition derived in the previous literature is therefore weakened by our analysis of corporate income taxation. This is an important implication since many fiscal equalization schemes are implemented in federations where corporate taxation takes the form of corporate income taxation. This is the case, for example, among Canadian provinces and German municipalities where the RTS inter alia redistributes tax bases of a corporate income tax. It is of course an open question whether our proposed alternative of tax revenue and private income equalization is a better option, in particular under the aspect of informational requirements. But our results at least show that the RTS also has its deficiencies and that it might be beneficial to look for alternatives or modifications. 


\section{Appendix}

Proof of equations (8)-(10). Totally differentiating (6), taking into account (5) and then applying the symmetry assumption yields

$$
(1-t) F_{k k} \mathrm{~d} k_{i}-\left(F_{k}-\rho r\right) \mathrm{d} t_{i}-(1-\rho t) \mathrm{d} r=0 .
$$

From (4) we obtain $\sum_{i=1}^{n} \mathrm{~d} k_{i}=0$. Hence, summing (33) over all countries gives

$$
-\left(F_{k}-\rho r\right) \sum_{i=1}^{n} \mathrm{~d} t_{i}-n(1-\rho t) \mathrm{d} r=0 .
$$

Setting all but one $\mathrm{d} t_{i}$ equal to zero immediately proves (8). Using (8) in (33) and doing the same for $j$ instead of $i$ yields (9). Form (7) and $\ell_{i}=\bar{\ell}$, we obtain $\mathrm{d} w_{i}=F_{k \ell} \mathrm{d} k_{i}$. Using (9) in this relation proves (10).

Pareto-efficient (cooperative) solution. To characterize the cooperative solution, consider a social planner that maximizes the countries' joint welfare given by

$$
\sum_{j=1}^{n} U\left(c_{j}, g_{j}\right)=\sum_{j=1}^{n} U\left(r \bar{k}+w_{j} \bar{\ell}+\pi_{j}, t_{j} \phi_{j}\right)
$$

where $\phi_{j}, \pi_{j}, r, k_{j}$ and $w_{j}$ depend on the tax rates according to (1), (2) and (8)-(10). Maximizing (35) with respect to $t_{i}$ and applying the symmetry property yields

$$
U_{c}\left(n \bar{k} \frac{\partial r}{\partial t_{i}}+\bar{\ell} \sum_{j=1}^{n} \frac{\partial w_{j}}{\partial t_{i}}+\sum_{j=1}^{n} \frac{\partial \pi_{j}}{\partial t_{i}}\right)+U_{g}\left(\phi+t \sum_{j=1}^{n} \frac{\partial \phi_{j}}{\partial t_{i}}\right)=0 .
$$

From (1), (2) and (8)-(10) we obtain $\sum_{j=1}^{n} \partial w_{j} / \partial t_{i}=0, \sum_{j=1}^{n} \partial \pi_{j} / \partial t_{i}=-\phi-n(1-$ $\rho t) \bar{k}\left(\partial r / \partial t_{i}\right)$ and $\sum_{j=1}^{n} \partial \phi_{j} / \partial t_{i}=-n \rho \bar{k}\left(\partial r / \partial t_{i}\right)$. Inserting into (36) gives

$$
U_{c}\left(-\phi+n \rho t \bar{k} \frac{\partial r}{\partial t_{i}}\right)+U_{g}\left(\phi-n \rho t \bar{k} \frac{\partial r}{\partial t_{i}}\right)=0
$$

and, thus, the Samuelson rule $U_{g} / U_{c}=1$.

\section{References}

Baretti, C., Huber, B. and K. Lichtblau (2002), 'A Tax on Tax Revenue: The Incentive Effects of Equalizing Transfers: Evidence from Germany', International Tax and Public Finance 9, 391-408.

Bayoumi, T. and P. Masson (1995), 'Fiscal Flows in the United States and Canada: Lessons for Monetary Union in Europe', European Economic Review 39, 253-274. 
Boadway, R. (2004), 'The Theory and Practice of Equalization', CESifo Economic Studies 50, 211254.

Bucovetsky, S. and M. Smart (2006), 'The Efficiency Consequences of Local Revenue Equalization: Tax Competition and Tax Distortions', Journal of Public Economic Theory 8, 119-44.

Büttner, T. (2006), 'The Incentive Effect of Fiscal Equalization Transfers on Tax Policy', Journal of Public Economics 91, 1533-54.

Dahlby, B., and N.A. Warren (2003), 'The Fiscal Incentive Effects of the Australian Equalisation System', Economic Record 79, 434-445.

DePater, J.A. and G.M. Myers (1994), 'Strategic Capital Tax Competition: A Pecuniary Externality and a Corrective Devise', Journal of Urban Economics 36, 66-78.

Devereux, M., Lockwood, B. and M. Redoano (2008), 'Do Countries Compete over Corporate Tax Rates?', Journal of Public Economics 92, 1210-1235.

Egger, P. and H. Raff (2015), 'Tax Rate and Tax Base Competition for Foreign Direct Investment', International Tax and Public Finance 22, 777-810.

Egger, P., Köthenbürger, M. and M. Smart (2010), 'Do Fiscal Transfers Alleviate Business Tax Competition? Evidence from Germany', Journal of Public Economic 94, 235-246.

Fenge, R. and M. Wrede (2007), 'EU Financing and Regional Policy: Vertical Fiscal Externalities when Capital is Mobile', Finanzarchiv 63, 457-476.

Gaigné, C. and S. Riou (2007), 'Globalization, Asymmetric Tax Competition, and Fiscal Equalization', Journal of Public Economic Theory 9, 901-925.

Genschel, P. and P. Schwarz (2011), 'Tax Competition: A Literature Review', Socioeconomic Review 9, 339-370.

Hauptmeier, S., Mittermaier, F. and J. Rincke (2012), 'Fiscal Competition over Taxes and Public Inputs', Regional Science and Urban Economics 42, 407-419.

Hendriks, J. Peralta, S. and S. Weber (2008), 'Competition in Taxes and Investment under Fiscal Equalization', Journal of Public Economics 92, 2392-2402.

Janeba, E. and W. Peters (2000), 'Implikationen des kommunalen Finanzausgleichs auf den Standortund Steuerwettbewerb [Implications of Intergovernmental Revenue Sharing on Tax Competition]', Beihefte der Konjunkturpolitik (Applied Economics Quarterly) 50, 35-53.

Köthenbürger, M. (2002), 'Tax Competition and Fiscal Equalization', International Tax and Public Finance 9, 391-408.

Kotsogiannis, C. (2010), 'Federal Tax Competition and the Efficiency Consequences for Local Taxation of Revenue Equalization', International Tax and Public Finance 17, 1-14.

Lui, Y. (2014), 'Does Competition for Capital Discipline Governments? The Role of Fiscal Equalization', International Tax and Public Finance 21, 345-374.

Mélitz, J. and F. Zumer (2002), 'Regional Redistribution and Stabilization by the Center in Canada, France, the UK and the US: A Reassessment and New Tests', Journal of Public Economics 86, 263-286.

Ogawa, H. and W. Wang (2016), 'Asymmetric Tax Competition and Fiscal Equalization in a Repeated Game Setting', International Review of Economics and Finance 41, 1-10.

Silva, E.C.D. (2016), 'Tax Competition and Federal Equalization Schemes with Decentralized Leadership', International Tax and Public Finance, forthcoming. 
Smart, M. (1998), 'Taxation and Deadweight Loss in a System of Intergovernmental Transfers', Canadian Journal of Economics 31, 189-206.

Smart, M. (2007), 'Raising Taxes through Equalization', Canadian Journal of Economics 40, 11881212.

Wang, W., Kawachi, K. and H. Ogawa (2014), 'Fiscal Transfer in a Repeated-Interaction Model of Tax Competition', FinanzArchiv 70, 556-566.

Wildasin, D.E. (1989), 'Interjurisdictional Capital Mobility: Fiscal Externality and a Corrective Subsidy', Journal of Urban Economics 25, 193-212.

Wilson, J.D. (1986), 'A Theory of Interregional Tax Competition', Journal of Urban Economics 19, 296-315.

Wilson, J.D. (1999), 'Theories of Tax Competition', National Tax Journal 52, 296-304.

Wilson, J.D. and D. Wildasin (2004), 'Theories of Tax Competition: Bane or Boon', Journal of Public Economics 88, 1065-1091.

Wrede, M. (2014), 'Agglomeration, Tax Competition, and Fiscal Equalization', International Tax and Public Finance 21, 1012-1027.

Zodrow, G. and P. Mieszkowski (1986), 'Pigou, Tibout, Property Taxation and the Underprovision of Public Goods, Journal of Urban Economics 19, 356-370. 